\title{
Orthodontic endodontic relationship, a multidisplinary approach and consideration
}

\author{
Al Anood Al-Harbi ${ }^{1}$ and Deema AlShammery ${ }^{2 *}$ \\ ${ }^{1}$ Postgraduate orthodontic resident, Riyadh colleges of Dentistry and Pharmacy, Saudi Arabia \\ ${ }^{2}$ Department of Preventive Dentistry, Riyadh colleges of Dentistry and Pharmacy, Saudi Arabia
}

\begin{abstract}
This is a review paper of information on the relationship between endodontics and orthodontics during treatment planning decisions. This relationship ranges from the effect of orthodontic tooth movement on the successful of endodontically treated teeth and the potential for resorption during tooth movement, to the clinical management of teeth requiring integrated endodontic and orthodontic treatment.
\end{abstract}

\section{Introduction}

Orthodontic Endodontic consideration is one of the important topic in Dentistry that has been discussed many years ago. movement of endodontically treated teeth was approached with caution for many years, and many precaution was considered during applying orthodontic movement to these teeth.

The aim of this review is to determine issues to be considered for endodontic terms before orthodontic treatment, the alterations which may be occurred in the pulp during and after orthodontic treatment and how these changes affect the treatment decision.

\section{Literature review}

Studies shown that orthodontic tooth movement impact on the viability of the dental pulp and pulpal injury may occur [1]. The explanation of this phenomena is primarily due to an alteration in the blood vessels in the apical periodontium and those entering the pulp. Clinically the teeth may have altered sensations to stimuli [2].

Oppenheim [3,4] showed some signs of severe pulpal degeneration in all human cases using a labio lingual expansion appliance. As a result, he recommended the use of light intermittent forces to reduce damage to the dental tissues and provide time for possible repair.

Many literature reviewed supports the fact that orthodontic tooth movement can cause degenerative and/or inflammatory responses in the dental pulp of teeth with completed apical formation, while Pulps in teeth with an incomplete apical foramen, whilst not immune to adverse action during tooth movement, have a reduced risk for these responses [5].

Orthodontic movement can carried out on endodontic treated teeth. As it is well known that mild resportion is normal during orthodontic treatment, Bender et al. [6] mentioned that there will be a reduction in the amount of resorption seen in endodontically treated. he suggested that the loss of the release of neuropeptides from a pulp that has been removed, would result in a decrease of the CGRP-IR fibers and. Their suggestions have been documented in many literature review and supported by Bondemark et al. [7].
Regarding the movement of Endodontically treated teeth, it was stated that it can be moved orthodontically as readily as teeth with vital pulps [8]. If teeth require root canal treatment during orthodontic movement, it is recommended that the root canals be cleaned, shaped and an interim dressing of calcium hydroxide be placed [9]. In other hand, A traumatized tooth in which exhibits resorption, there is a greater chance that orthodontic tooth movement will enhance the resorptive process. If a tooth has been severely traumatized (intrusive luxation/avulsion) there may be a greater incidence of resorption, with or without root canal treatment $[9,10]$.

Regarding orthodontic treatment of tooth associated with Cystlike lesion, Paduano et al. [11] reported a successful treatment with endodontic and orthodontic combined treatment in a case presentation of a patient who had cyst-like lesion signs radiographically. After nonsurgical endodontic treatment of an 18-year-old patient, orthodontic treatment was carried out, and it was observed that large periapical lesion was totally healed after 2 years. The authors stated that orthodontic tooth movement can be applied without a need to wait for completely healing after root treatment of periapical cyst-like lesions was completed.

\section{Conclusion}

Orthodontic tooth movement can be carried out successfully with endodontically treated teeth. It is always recommend to use of moderate and intermittent forces enables sufficient tooth movement, limits the damage in the pulp, and allows the damaged pulp healing.

Completion the Endodontic treatment of teeth, with a careful clinical and radiographical evaluation before orthodontic treatment is a key factor that lead to successful orthodontic movement.

Correspondence to: Deema AlShammery, Department of Preventive Dentistry, Riyadh colleges of Dentistry and Pharmacy, Saudi Arabia; E-mail: deema@riyadh.edu.sa

Key words: endodontics, orthodontics, pulp, root resorption

Received: December 03, 2017; Accepted: December 18, 2017; Published: December 21, 2017 
Teeth which were subject to trauma are more sensitive to orthodontic movement so clinical and radiographic evaluations must be carried out carefully before force is applied to these teeth. The patient must also be informed about the possible complications and the possibility of prolongation of treatment period.

\section{References}

1. Seltzer S, Bender IB (1984) The Dental Pulp, 3rd edn. Philadelphia: J. B. Lippincott Company, 210-211.

2. Burnside RR, Sorenson FM, Buck DL (1974) Electric vitality testing in orthodontic patients. Angle Orthod 44(3): 213-217. [Crossref]

3. Oppenheim A (1936) Biologic orthodontic therapy and reality. Angle Orthodontist T 153.

4. Oppenheim A (1937) Biologic orthodontic therapy and reality. Angle Orthodontist U 58-59.

5. Hamilton RS, Gutmann JL (1999) Endo-ortho relationships a review of integrated treatment planning challenges. Int Endod J 32(5): 343-360. [Crossref]
6. Bender IB, Byers MR, Mori K (1997) Periapical replacement resorption of permanent, vital, endodontically treated incisors after orthodontic movement: report of two cases. J Endod 23(12): 768-773. [Crossref]

7. Bondemark L, Kurol J, Hallonsten A-L, Andreasen JO (1997) Attractive magnets for orthodontic extrusion of crown-root fractured teeth. Am J Orthod Dentofacial Orthop 112(2): 187-193. [Crossref]

8. Mattison GD, Delivanis HP, Delivanis PD, Johns PI (1984) Orthodontic root resorption of vital and endodontically treated teeth. J Endod 10: 354-358. [Crossref]

9. Avsar A, Akbaş S, Ataibiş T (2009) Traumatic dental injuries in children with attention deficit/hyperactivity disorder. Dent Traumatol 25: 484-489. [Crossref]

10. Jacobs SG (1995) The treatment of traumatized permanent anterior teeth: case report \& literature review. Part I. Management oftruded incisors. Aust Orthod J 213-218. [Crossref]

11. Paduano S, Uomo R, Amato M, Riccitiello F, Simeone M (2013) Cyst-like periapical lesion healing in an orthoodntic patient: A case report with five-year follow-up. G Ital Endod 27: 95-104

Copyright: @2017 Al-Harbi AA. This is an open-access article distributed under the terms of the Creative Commons Attribution License, which permits unrestricted use, distribution, and reproduction in any medium, provided the original author and source are credited. 